\title{
Economic Appraisal of Lift Irrigation Schemes-Benefit Cost Ratio \& Internal Rate of Return: Case Study of Mhaisal Lift Irrigation Scheme
}

\author{
Vidya Purandare ${ }^{1}$ Dr.V.H.Bajaj ${ }^{2}$ \\ 1. Associate Professor, Water and Land Management Institute, Aurangabad(M.S), INDIA \\ 2. Professor, Dept. of Statistics, Dr. BabasahebAmbedkarMarathawadaUniversityAurangabad(M.S) INDIA
}

\begin{abstract}
Development of Water Resources Projects is a complex task \& needs huge investments. This makes it imperative to take a conscious, judicious and sound decision for investment and construction of projects. Any casual approach can lead to a variety of problems in execution, time and cost overruns offsetting the economics of the project. It is therefore necessary that projects are planned based on adequate surveys and investigations, well engineered, soundly designed \& evaluated based on reliable economics. The benefit cost ratio and internal rate of return are the two techniques which help take decision regarding economic feasibility \& sanctioning of projects in India. The Mhaisal lift irrigation project satisfies all the necessary norms \& irrigation has been executed since 2004-2005.
\end{abstract}

Keywords:- benefit-cost ratio, discounting, internal rate of return, lift irrigation project, project appraisal.

\section{INTRODUCTION:}

Water that flows through the rivers from mountains to oceans possesses plentiful energy that can turn the wheels of industries, light the homes besides being an important source of drinking water as well as to provide irrigation to crops that can feed people. But harnessing these topotentials involve huge investments. Various studies are required to be appraised carefully to establish their techno-economic viability. The process of formulation and appraisal of cost estimates of Water Resources Projects including Lift Irrigation Schemes (WRP) are of paramount importance for their clearance by Technical Advisory Committee, TAC \& investment approval by Planning Commission/NITI. The present paper discusses the economic viability of WRP using Benefit Cost (B/C) Ratio and Internal Rate of Return (IRR) methodsas per the detailed guidelines for preparation of project estimates for WRP laid down by Central Water Commission. The results clearly show that the LIS satisfies the norms for acceptance of projects.

\section{NECESSITY OF PROJECT APPRAISAL \& EVALUATION:}

Economic analysis of irrigation projects is necessary to test the economic feasibility of irrigation project and ranking of different alternatives in order to determine priority in investments. Economic Project Appraisal should determine whether a project is acceptable and is the best alternative. Appraisal is the analysis of costs \&benefits before project is undertaken. The analysis is ex-ante.Evaluation is the analysis of costs and benefits undertaken after the project has commissioned (after a minimum of 5 to 10 years). The analysis is ex-post. It assess the developmental impact of the project.Economic Project Appraisal should determine whether a project is acceptable and is the best alternative. It also helps in ranking of different alternatives in order to determine priority in investments.

\section{TECHNIQUES OF SELECTING A PROJECT}

3.1 Present methodology;

The benefit cost ratio method, second Irrigation Commission, 1972, Government of India ${ }^{[1]}$ endorsed the use of benefit cost ratio for judging the economic soundness of irrigation projects.

$\mathrm{B} / \mathrm{C}$. Ratio has to be $>=1.5$, in general

$\mathrm{B} / \mathrm{C}$. Ratio can be $>=1.0$, for irrigation projects in drought prone, flood prone or tribal areas.

Net annual benefits $\quad=\mathrm{B} / \mathrm{C}$ is the ratio required.

Annual Costs

3.2 Discounted cash flow techniques ${ }^{[2]}$ 
The B.C. Ratio mentioned above ignores time value of this is taken care of in discounting techniques suggested for economic analysis of WRP. Because projects vary widely in the pattern of their costs \& benefits over time, DCF is necessary to place them on a common present value basis for comparison. The techniques are :

- Net present method

- Benefit cost ratio method

- Internal Rate of Return / Economic Rate of Return method.

- Discounted B - C Ratio = Present worth of total benefits

Present worth of total costs

- Net Present Worth = Present worth of Benefit - Present worth of cost

\subsubsection{Discounting ${ }^{[3}$}

- IRR is the discount rate at which discounted benefit cost ratio is $=1$

Discounting is the process of adjusting the future values to the present by a discount rate. It takes care of time value of money. As the time passes the value of money changes. In economic analysis of irrigation projects, LIS or for that matter, any project, it is necessary to convert all cost \& benefit streams to same level called base year. Discounting factors can be used for determining present worth of future payments.

3.2.2 Discounting factors.

$\mathbf{P}=$ Present value $\quad \mathbf{i}=\%$ annual discount rate $\mathbf{F}=$ Future value

$\mathbf{N}=$ Number of annual discount periods or Number of years of gap between $\mathbf{P} \& \mathbf{F}$

\subsubsection{Single Payment Present Worth Factor.}

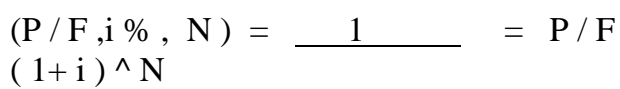

3.2.2.2Equal ( Uniform Series) Payment Present Worth Factor.

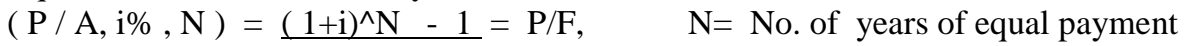
$\mathrm{i}(1+\mathrm{i})^{\wedge} \mathrm{N}$

- Present Worth ( Value $)$ of Cost $=$ PWC $($ or PVC $)$

$\mathrm{N}$

$\mathrm{PWC}=\Sigma(\mathrm{P} / \mathrm{F}, \mathrm{i} \%, \mathrm{t}) * \mathrm{Ct}$

$\mathrm{t}=1$

- Present Worth (Value ) of Benefits = PWC (or PVC)

$\mathrm{N}$

$\mathrm{PWB}=\Sigma(\mathrm{P} / \mathrm{F}, \mathrm{i} \%, \mathrm{t})^{*} \mathrm{Bt}$

$\mathrm{t}=1$

NPW $=$ Net present worth $=$ PWB - PWC

BENEFIT COST RATIO $(\mathrm{B} / \mathrm{C})=\underline{\mathrm{PWB}}$

( Discounted) PWC

3.2.2.3 IRR can be calculated by Interpolation method or Microsoft excel can be used.

- Interpolation method

IRR $=$ Lower Discount Rate + Diff.between two discount rates $*$ [B/C at lower D.R - 1]

[ Diff. between $\mathrm{B} / \mathrm{C}$ ratios at two discountrates]

Norm assuggested by CWC is IRR has to be $>=12 \%$ in general \& $10 \%$ for drought, flood prone /tribal areas.

\subsection{The Case Study - Mhaisal Lift Irrigation Scheme. ${ }^{[4]}$}

The present chapter deals with the changes that have taken place due to irrigation, particularly the transformation occurred because ofMhaisal Lift Irrigation Project. The benefit cost ratio during pre-project situation \& post project time period are estimated based on the actual data of crop pattern \& prices of agriculture produce.

\subsection{The Background}

\subsubsection{The Maharashtra State}

Maharashtra is the third largest State in Union of India considering population as well as area. It is located in the north center of Peninsular India.

The River Krishna (Fig.1) which originates in sahyadri ranges flow down on eastern side. This carries plenty of water The water in basin Krishna after running $30 \mathrm{kms}$. flows parallel to sahyadri ranges, from north to south. 
After crossing Karad, it flows eastward towards Sangli. Also, the waters in basins of Krishna, warna\&Koyna flow parallel to sahyadri range of hills, this deprives some areas between sub basins to get water by gravity flow.

(The arrow should be pointed at blue line of Krishna river ) please make correction

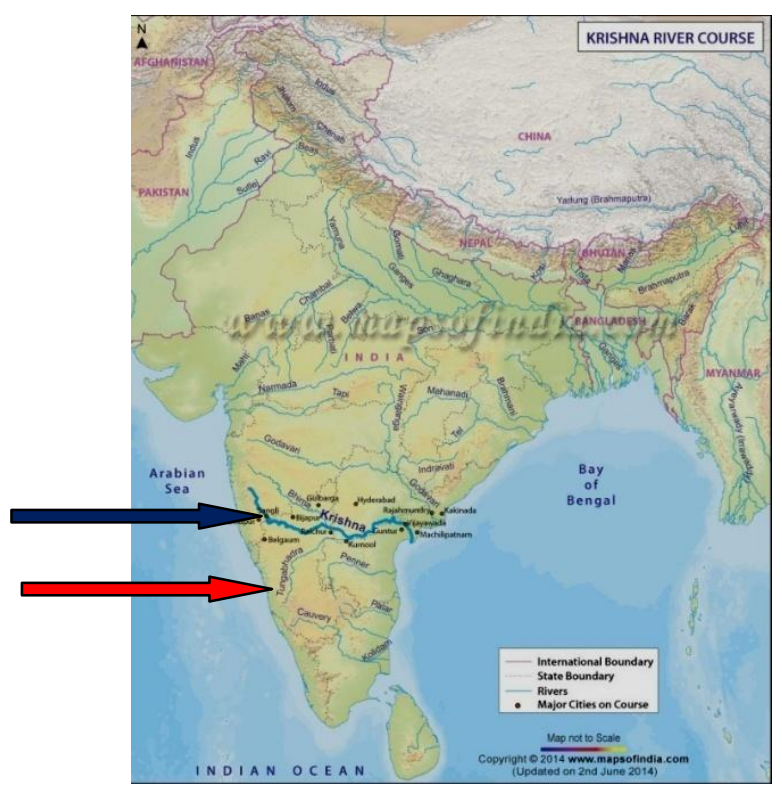

Fig.1 Krishna River course

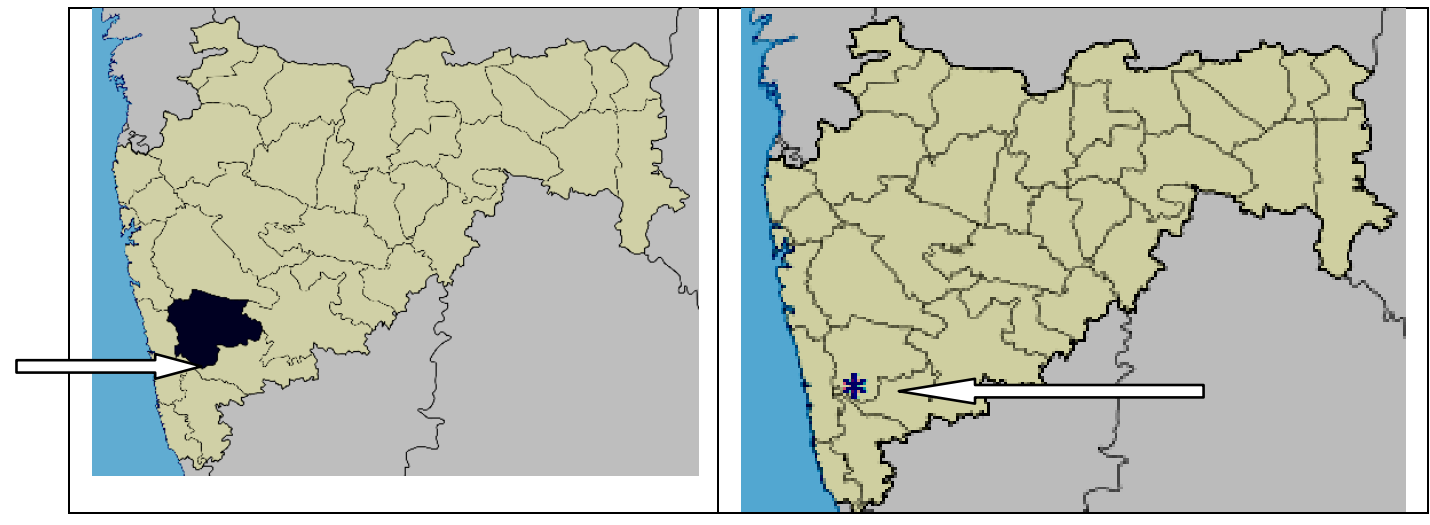

Fig.2 Maharashtra: Satara District Fig.3 Location of Koyna Dam

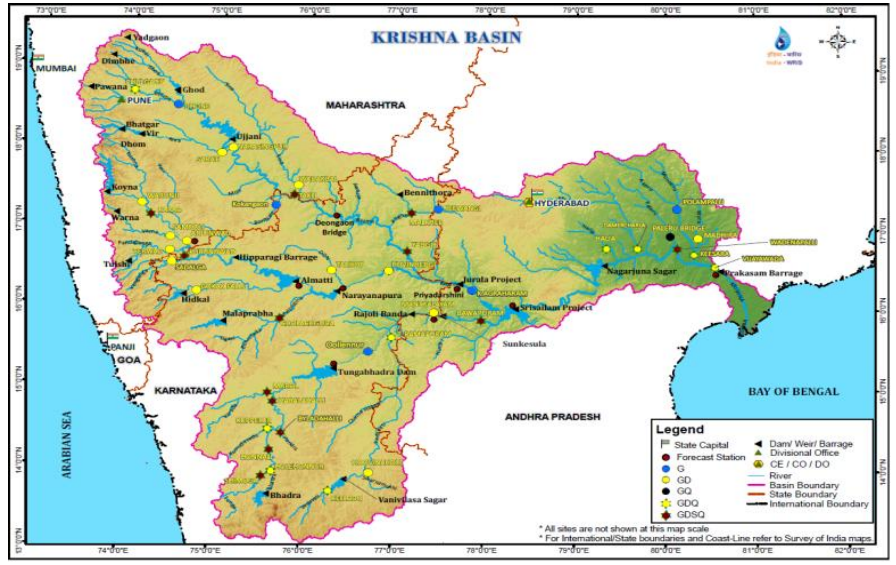

Fig.4 Krishna Basin 
The rainfall in Sangli\&solapur is uneven, scanty and not reliable also. The talukasJat, Sangola, Mangalaveda are at 600 to 750 feet higher elevation from Krishna River. Farming is not beneficial. This area is highly drought prone. Practically, no big dams can be constructed in these areas to give gravity flow irrigation facility. To supply water for the drought prone areas, for drinking, irrigation and water use as per Krishna Water Dispute Tribunal (KWDT), the Krishna Koyna Lift Irrigation Scheme (KKLIS) was sanctioned in the year 1984. Lift irrigation projects are the only possible solution.

\subsubsection{About Mhaisal Scheme ${ }^{[5]}$}

Water from Krishna river at Mhaisal KT weir, Tal.Miraj, Dist. Sangli\& water from Fig.Koyna reservoir ( ShivajiSagar)is lifted to irrigate $81697 \mathrm{Ha}$. of area in Miraj, Kavathemahakal, Jath\&Tasgaontalukas of SanglidistrictandSangola, MagalawedhaTalukas of Solapur district as 66550 Ha. equivalent area by tank filling in Jath, Sangola,MagalawedhaTalukas.In Kharif season,5860Mcft(5.86 TMC)of water will be available from runoff of the river Krishna. Infair weather season,fromKoyna Dam, 11580Mcft.( $11.58 \mathrm{TMC})$ of water is lifted by releasing in river Krishna.

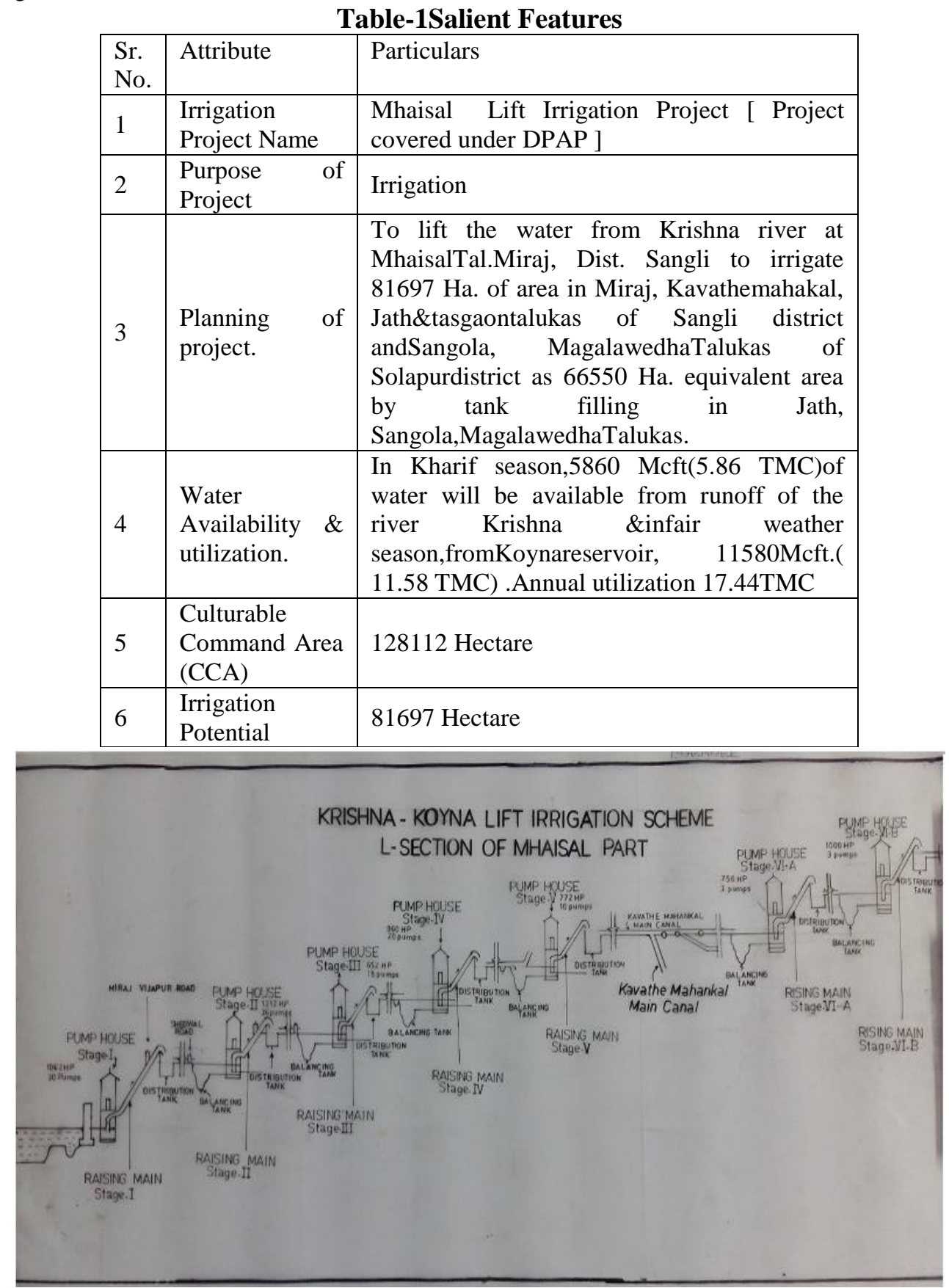

Fig. 5 Mhaisal LIS, L-Section 


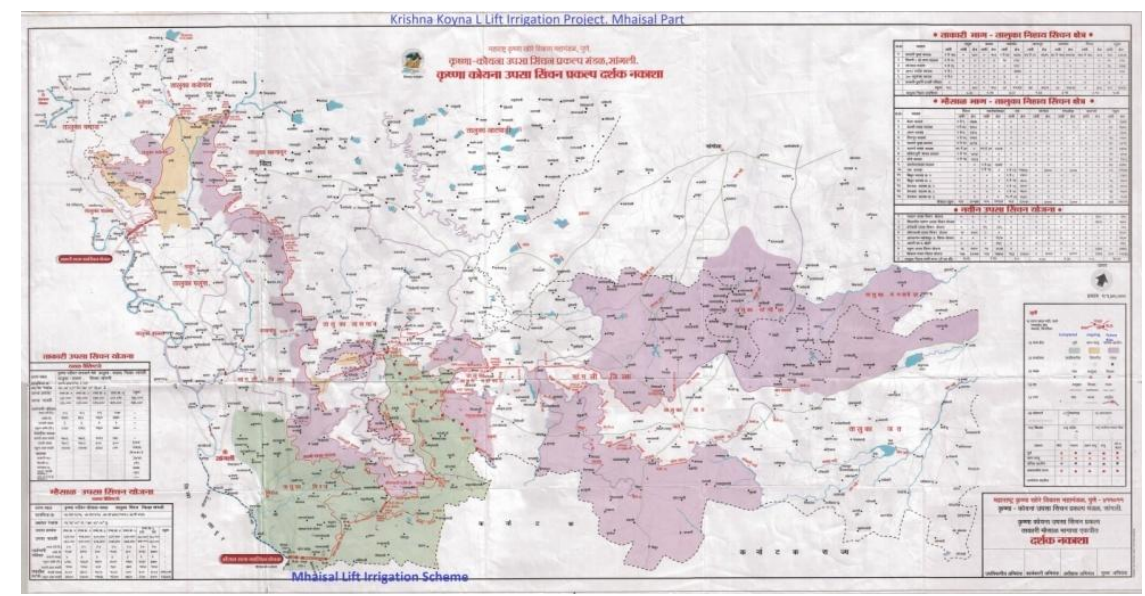

Fig .6 Command map of Krishna Koyna LIS -Mhaisal LIS is a part of it

( Green shade represents the completed work, purple color indicates future plan of development)

\subsection{Economic Appraisal of Mhaisal Irrigation project : B/C Ratio \& IRR}

The main aim of Mhaisal lift irrigation scheme was to bring the drought prone area under irrigated agriculture. The economic appraisal requires the data relating to cropping pattern viz. that of before project and after project. Mhaisal is a part of Krishna Koyna Lift Irrigatuion Scheme (KKLIS). The irrigable command area of KKLIS is 109127 hectares . $75 \%$ of this, 81697 hectares is covered by Mhaisal LIS.

\subsection{Assumptions}

a) The base year referred is 2013-14. Life of Mhaisal LIS project is 100 years.

b) The data regarding cost of pumping system \& raising main of Mhaisal LIS is $75 \%$ of that ofKKLIS.

c)The agriculture prices of year 2013-14 are referred.

d) As Mhaisalproject is a lift on Krishna river, no displace of people was done \& hence there is no rehabilitation cost incurred.

e) All the costs are converted to year $2013-14$ by compounding the past values \& discounting the future values.

\section{Insert SPACE}

5.2 The benefit cost ratio. ${ }^{[7]}$

The Post project( table.1) \&Pre project crop patterns (table.2) along with total net benefits, the benefit cost ratio calculations (table.3) total cost of the project (table. 4), are as given the tables below ${ }^{[4],[5],[9],[8] \text {. }}$

Table -

Mhaisal Lift Irrigation Project, Dist. Sangli

Benefits for post-project cropping pattern

\begin{tabular}{|c|c|c|c|c|c|}
\hline \multirow[t]{2}{*}{ Sr.No. } & \multirow[t]{2}{*}{ Particulars } & \multicolumn{2}{|c|}{$\begin{array}{l}\text { Area of Mhaisal } \\
\text { ( in } \mathrm{Ha})\end{array}$} & \multirow[t]{2}{*}{$\begin{array}{l}\text { Net } \\
\text { Benefits/Ha }\end{array}$} & \multirow[t]{2}{*}{$\begin{array}{l}\text { Net value } \\
\text { (Rs. In } \\
\text { Lakhs) }\end{array}$} \\
\hline & & 81697 & & & \\
\hline & & $\begin{array}{l}\text { Crop } \\
\%\end{array}$ & $\begin{array}{l}\text { Area in } \\
\mathrm{Ha}\end{array}$ & & \\
\hline $\mathrm{A}$ & Perennial & & & & \\
\hline 1 & Sugarcane & 3 & 2450.91 & 234020 & 5735.6 \\
\hline 2 & Sugarcane(unirrigated) & 4 & 3267.88 & 95519 & 3121.4 \\
\hline 3 & Fruits(Grapes) & 12 & 9803.64 & 157226 & 15413.9 \\
\hline \multirow[t]{2}{*}{4} & Onion(mixed crop) & 7 & 5718.79 & 181684 & 10390.1 \\
\hline & Perennial Total & 26 & 21241.22 & & \\
\hline B & Two Seasonal crops & & & & \\
\hline \multirow[t]{2}{*}{1} & L.S.Cotton & 2 & 1633.94 & 83597 & 1365.9 \\
\hline & Two Seasonal Total & 2 & 1633.94 & 83597 & \\
\hline $\mathbf{C}$ & Kharif & & & & \\
\hline
\end{tabular}




\begin{tabular}{|l|l|l|l|l|l|}
1 & Hybrid Jawar & 16 & 13071.52 & 6461 & 844.6 \\
\hline 2 & Maize & 10 & 8169.7 & 11262 & 920.1 \\
\hline 3 & Vegetables & 20 & 16339.4 & 305362 & 49894.3 \\
\hline 4 & Sun flower & 8 & 6535.76 & 14733 & 962.9 \\
\hline & KharifUnIrrigated & & & & \\
\hline 1 & Ground Nuts & 5 & 4084.85 & 5254 & 214.6 \\
\hline 2 & Pulses & 0 & 0 & 0 & \\
\hline 3 & Bajara & 0 & 0 & 0 & \\
\hline 4 & Hybrid Jawar & 10 & 8169.7 & 6461 & 527.8 \\
\hline & Kharif Total & 69 & 56370.93 & & \\
\hline D & Rabbi Seasons & & & & \\
\hline 1 & Wheat & 2 & 1633.94 & 11289 & 184.5 \\
\hline 2 & Hybrid Jawar & 14 & 11437.58 & 7714 & 882.3 \\
\hline 3 & Sun flower & 2 & 1633.94 & 14733 & 240.7 \\
\hline 4 & Gram & 3 & 2450.91 & 24691 & 605.2 \\
\hline 5 & Vegetables & 5 & 4084.85 & 47550 & 1942.3 \\
\hline 6 & Saf flower & 3 & 2450.91 & 14733 & 361.1 \\
\hline & Rabi Total & 29 & 23692.13 & & \\
\hline E & Hot weather crops & & & & \\
\hline 1 & Ground Nuts & 2 & 1633.94 & 5254 & 85.8 \\
\hline & Ground Nut Total & 2 & 1633.94 & & \\
\hline & Grand Total & 128 & 104572.16 & & $\mathbf{9 3 6 9 3 . 2}$ \\
\hline
\end{tabular}

1. LET The full table be on one page only. Let it not get bifurcated in two pages

2. Let the table 2 be adjusted in such a fashion that the titles be in one line i.e. broaden the columns

3 The table 3 be adjusted as given now. The last value should be on the same page

Table. 2

Mhaisal Lift Irrigation Project, Dist. Sangli

Benefits for pre-project cropping pattern

\begin{tabular}{|l|l|l|l|l|l|}
\hline Sr.No. & Particulars & \multicolumn{2}{|l|}{ Area of Mhaisal (in Ha) } & Net Benefits /Ha. & $\begin{array}{l}\text { Net } \\
\text { Rs.In Lakhs }\end{array}$ \\
\hline & & \multicolumn{2}{|l|}{81697} & & \\
\hline & \multicolumn{2}{|l|}{$\begin{array}{l}\text { Crop } \\
\%\end{array}$} & Area in Ha & & \\
\hline A & Kharif & & & & \\
\hline 1 & Sugarcane & 4 & 3267.9 & 95519 & 3121.4 \\
\hline 2 & Kh. Pulses & 16 & 13071.5 & 25679 & 3356.6 \\
\hline 3 & Groundnut & 16 & 13071.5 & 5254 & 686.8 \\
\hline & & & & & \\
\hline B & Rabi & & & & 2772.9 \\
\hline 1 & $\begin{array}{l}\text { Rabi } \\
\text { jawar }\end{array}$ & 44 & 35946.7 & 7714 & 604.2 \\
\hline 2 & Bajara & 16 & 13071.5 & 4622 & 454.1 \\
\hline 3 & Wheat & 4 & 3267.9 & 13897 & 10996.1 \\
\hline & $\begin{array}{l}\text { Grand } \\
\text { Total }\end{array}$ & 100 & 81697.0 & 152685 & \\
\hline
\end{tabular}

Table .3

Mhaisal Lift Irrigation Project, Dist. Sangli 
B.C. Ratio CalculationsAmount in Rs. Lakhs

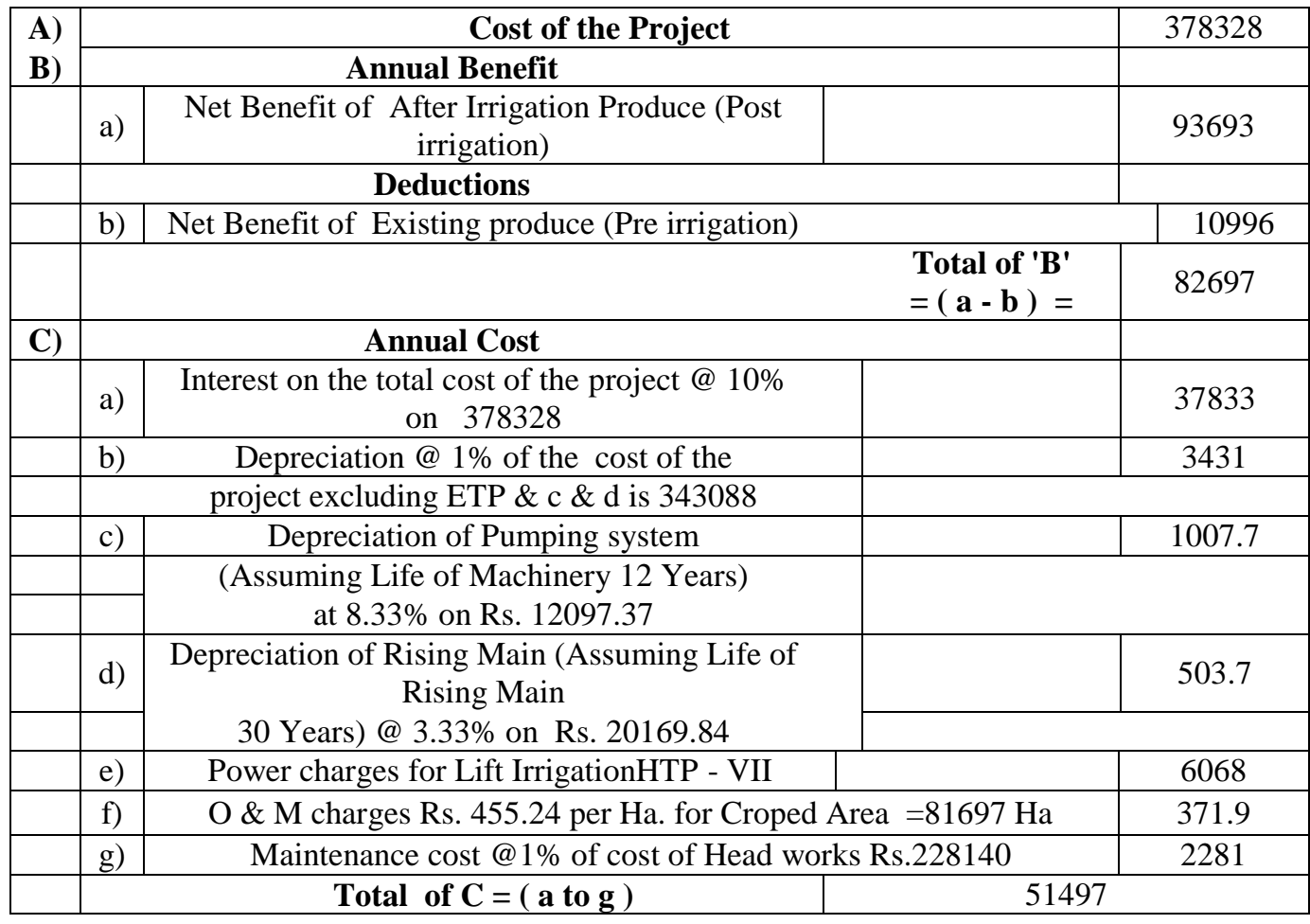

Benefit Cost Ratio $=\underline{\text { Net annual benefits }} \quad=\underline{82697}$ Annual Cost

\section{$=1.61$}

Mhaisal Lift Irrigation Project Circle, Sang \begin{tabular}{c|c|c|c|} 
Statement showing Expenditure Incurred on Mhaisal Lift Irrigation Project from 1984-85 to May 2016 & Rupees in lakhs \\
\hline
\end{tabular}

\begin{tabular}{|c|c|c|c|c|c|c|c|c|c|c|c|c|c|c|c|}
\hline \multirow{2}{*}{\begin{tabular}{l|} 
Sr. \\
No.
\end{tabular}} & \multirow{2}{*}{ Year } & \multicolumn{7}{|c|}{ Mhaisal Part } & \multirow{2}{*}{$\begin{array}{l}\text { capital } \\
\text { cost }\end{array}$} & \multirow{2}{*}{\begin{tabular}{|l} 
Base Year \\
$2013-14$
\end{tabular}} & \multirow{2}{*}{$1 /(1.1)^{\wedge} \mathrm{N}$} & \multicolumn{2}{|c|}{$\begin{array}{l}\text { Rupese in lakh } \\
\text { Discounting factor with } 10 \% \text { rat }\end{array}$} & \multicolumn{2}{|c|}{ Discounted } \\
\hline & & $\begin{array}{l}\text { Head } \\
\text { Work }\end{array}$ & Canal & Distbutaries & Building & \begin{tabular}{|l|} 
Land \\
Aquisition
\end{tabular} & E.T.P. & E.G.S. & & & & $\left.\mathrm{P}=\mathrm{F}^{*}\left[1 /(1.1)^{\wedge} \mathrm{N}\right)\right]$ & $\begin{array}{l}\text { ETP+EGS+ } \\
\text { LA }\end{array}$ & $\begin{array}{l}\text { ETP+EGS+ } \\
\text { RH+LA }\end{array}$ & Head works \\
\hline 1 & $1987-1988$ & 13 & 2.77 & 0 & 16 & 0 & 1.99 & 27.24 & 61 & -26 & 11.9 & 727.0 & 29.2 & 348.4 & 154.9 \\
\hline 2 & $1988-1989$ & 125.46 & 67.61 & 0 & 49.78 & 0.11 & 6.81 & 0.05 & 249.82 & -25 & 10.8 & 2706.7 & 7.0 & 75.5 & 1359.3 \\
\hline 3 & $1989-1990$ & 134.22 & 177.67 & 0 & 46.58 & 0.59 & 24.09 & 0 & 383.15 & -24 & 9.8 & 3773.9 & 24.7 & 243.1 & 1322.0 \\
\hline 4 & 1990 - 1991 & 39.61 & 102.85 & 0 & 32.48 & 0.37 & 7.44 & 0 & 182.75 & -23 & 9.0 & 1636.4 & 7.8 & 69.9 & 354.7 \\
\hline 5 & 1991 - 1992 & 272.56 & 104.87 & 0 & 81.32 & 2 & 28.72 & 0 & 489.47 & -22 & 8.1 & 3984.4 & 30.7 & 250.1 & 2218.7 \\
\hline 6 & $1992-1993$ & 135.77 & 118.68 & 0 & 54.77 & 1.45 & 91.47 & 0 & 402.14 & -21 & 7.4 & 2975.9 & 92.9 & 687.6 & 1004.7 \\
\hline 7 & 1993 - 1994 & 1596.24 & 333.63 & 0 & 93.79 & 30.37 & 198.45 & 0 & 2252.48 & -20 & 6.7 & 15153.6 & 228.8 & 1539.4 & 10738.7 \\
\hline 8 & \begin{tabular}{|c|}
$1994-1995$ \\
\end{tabular} & 3349.46 & 541.53 & 0 & 81.07 & 1.68 & 269.98 & 0 & 4243.72 & -19 & 6.1 & 25954.2 & 271.7 & 1661.4 & 20485.0 \\
\hline 9 & 1995 - 1996 & 3255.62 & 840.08 & 0 & 10.64 & 26.87 & 301.42 & 0 & 4434.63 & -18 & 5.6 & 24656.2 & 328.3 & 1825.3 & 18101.0 \\
\hline 10 & 1996 - 1997 & 5264.31 & \begin{tabular}{|l|}
1752.58 \\
\end{tabular} & 0 & 0 & 1.54 & 324.07 & 0 & 7342.5 & -17 & 5.1 & 37112.4 & 325.6 & 1645.8 & 26608.3 \\
\hline 11 & $1997-1998$ & \begin{tabular}{|l|l|}
5713.39 \\
\end{tabular} & \begin{tabular}{|l|}
1833.04 \\
\end{tabular} & 0 & 0 & 7.44 & 352.21 & 0 & 7906.08 & -16 & 4.6 & 36328.2 & 359.7 & 1652.6 & 26252.9 \\
\hline 12 & 1998 - 1999 & 3795.59 & 646.56 & 21.51 & 0 & 59.37 & 468.81 & 0 & 4991.84 & -15 & 4.2 & 20852.2 & 528.2 & 2206.3 & 15855.1 \\
\hline 13 & 1999 - 2000 & 3521.92 & 804.94 & 12.85 & 0 & 4.31 & 571.09 & 0 & 4915.11 & -14 & 3.8 & 18665.1 & 575.4 & 2185.1 & 13374.5 \\
\hline 14 & $2000-2001$ & 5975.56 & 1319.53 & 18.5 & 0 & 1.15 & 431.56 & 0 & 7746.3 & -13 & 3.5 & 26742.3 & 432.7 & 1493.8 & 20629.3 \\
\hline 15 & $2001-2002$ & 1808.8 & 455.39 & 65.02 & 0 & 0.99 & 381.66 & 0 & 2711.86 & -12 & 3.1 & 8511.0 & 382.7 & 1200.9 & 5676.8 \\
\hline 16 & $2002-2003$ & 3320.29 & 224.6 & 70.64 & 0 & 4.64 & 390.31 & 0 & 4010.48 & -11 & 2.9 & 11442.4 & 395.0 & 1126.8 & 9473.2 \\
\hline 17 & $2003-2004$ & 971.94 & 41.26 & 2.52 & 0 & 7.5 & 392.3 & 0 & 1415.52 & -10 & 2.6 & 3671.5 & 399.8 & 1037.0 & 2521.0 \\
\hline 18 & $2004-2005$ & 1996.42 & 669.31 & 10.67 & 0 & 0.03 & 455.55 & 0 & 3131.98 & -9 & 2.4 & 7385.0 & 455.6 & 1074.2 & 4707.5 \\
\hline 19 & $2005-2006$ & 2830.44 & 1724.41 & 28.78 & 0 & 0.03 & 558.88 & 0 & 5142.54 & -8 & 2.1 & 11023.5 & 558.9 & 1198.1 & 6067.3 \\
\hline 20 & $2006-2007$ & 3952.25 & 891.07 & 15.16 & 0 & 44.43 & 520.87 & 0 & 5423.78 & -7 & 1.9 & 10569.4 & 565.3 & 1101.6 & 7701.8 \\
\hline 21 & $2007-2008$ & 1235.84 & 47.93 & 30.08 & 0 & 0.09 & 550.75 & 0 & 1864.69 & -6 & 1.8 & 3303.4 & 550.8 & 975.8 & 2189.4 \\
\hline 22 & $2008-2009$ & 723.51 & 369.06 & 93.43 & 0 & 2.62 & \begin{tabular}{|l|l|}
674.34 \\
\end{tabular} & 0 & 1862.96 & -5 & 1.6 & 3000.3 & 677.0 & 1090.3 & 1165.2 \\
\hline 23 & $2009-2010$ & \begin{tabular}{|l|l|}
4592.79 \\
\end{tabular} & \begin{tabular}{|l|}
1620.77 \\
\end{tabular} & 1367.13 & 0 & 450.78 & 849.24 & 0 & 8880.71 & -4 & 1.5 & 13002.2 & 1300.0 & 1903.4 & 6724.3 \\
\hline 24 & $2010-2011$ & 4303.83 & \begin{tabular}{|l|}
5791.81 \\
\end{tabular} & 638.83 & 0 & 831.34 & 1025.7 & 0 & 12591.49 & -3 & 1.3 & 16759.3 & 1857.0 & 2471.7 & 5728.4 \\
\hline 25 & $2011-2012$ & 9039.65 & \begin{tabular}{|l|}
3397.42 \\
\end{tabular} & 1300.74 & 0 & 910.84 & 1099.3 & 0 & 15747.92 & -2 & 1.2 & 19055.0 & 2010.1 & 2432.2 & 10938.0 \\
\hline 26 & $2012-2013$ & 2258.46 & \begin{tabular}{|l|}
1000.51 \\
\end{tabular} & 515.29 & 0 & 69.36 & 1182.9 & 0 & 5026.55 & -1 & 1.1 & 5529.2 & 1252.3 & 1377.5 & 2484.3 \\
\hline 27 & $2013-2014$ & 1360.71 & \begin{tabular}{|l|}
2958.34 \\
\end{tabular} & 16000.8 & 0 & -1284 & 1274.8 & 0 & 20310.68 & 0 & 1.0 & 20310.7 & -9.2 & -9.2 & 1360.7 \\
\hline 28 & $2014-2015$ & 1857.21 & \begin{tabular}{|l|}
3826.67 \\
\end{tabular} & 11644.23 & 0 & 91.34 & 1283.6 & 0 & 18703.09 & 1 & 0.9 & 17002.8 & 1375.0 & 1250.0 & 1688.4 \\
\hline 29 & $2015-16$ & 1087.77 & 2337.69 & 2614.69 & 0 & 30.72 & 1031.6 & 0 & 7102.51 & 2 & 0.8 & 5869.8 & 1062.4 & 878.0 & 899.0 \\
\hline 30 & $2016-2017$ & 474.18 & 27.86 & 0 & 0 & 0 & 209.47 & 0 & 711.51 & 3 & 0.8 & 534.6 & 209.5 & 157.4 & 356.3 \\
\hline & TOTAL & 75006.8 & 34030.4 & 34450.87 & 466.43 & 1297.96 & 14959 & 27.29 & 160239.3 & & & & & 35150.1 & 228140.5 \\
\hline
\end{tabular}

5.3 The internal Rate of return ${ }^{[7]}$

The internal rate of return of the Mhaisal project is $11.2 \%$ estimated using M.S.Office-Excell

\section{CONCLUSIONS}


1. The economic appraisal of the project which is carried out using Benefit Cost ratio \& Internal Rate of Return clearly indicates that the project satisfies all the norms as B/C >1.00 and internal Rate of Return is $>10 \%$, the present project is in draught prone area.

2. The evaluation study needs to be carried out after the completion of project.

3. The present study does not include any indirect, secondary benefits due to the project.

4. The social benefit viz. availability of drinking water in a highly drought are is also not being considered.

\section{ACKNOWLEDGEMENT}

The authors are thankful to the authorities of KrishnaKoyna Lift Irrigation Circle (KKLIC), Sangli\& all the offices under KKLIC, Water Resources Department, Government of Maharashtra for providing the necessary data $\&$ the guidance.

\section{REFERENCES}

[1] Report of Irrigation Commission, Govt. of India, 1972

[2] Baswan Sinha \& Ramesh Bhatia, Economic Appraisal of Irrigation Projects in India, 1984.

[3] Economics of Irrigation Water Management,WALMI publication No 51, 1999.

[4] The Detailed Project Report of Krishna Koyna Lift Irrigation Scheme ( KKLIS), Water Resources Department,Government of Maharashtra, 1986.

[5] Revised estimates of Mhaisal LIS, 2014.

[6] White paper on Irrigation, Govt. of Maharashtra, India 2012.

[7] Central Water Commission,Ministry of Water Resources - Guidelines for Preparation of Detailed Project Reports (DPR) of Irrigation \&Multipurpose Projects, 2010.

[8] Irrigation Status Reports,WRD, Govt. of Maharashtra, 2016.

[9] Data of Krishna river flows, Offices under KKLIS circle, Sangli, 2016. 